\title{
Teaching Translation Using Project-Based-Learning: Saudi Translation Students Perspectives
}

\author{
Mubarak Alkhatnai \\ Department of English Language and Translation \\ College of Languages and Translation \\ King Saud University, Riyadh, Saudi Arabia
}

\begin{abstract}
In the last few years, interest in improving the teaching of translation increased immensely. Proposals of introducing many methods to raise students' involvement and centeredness in the process evolved and many concepts from other disciplines were implemented. One of these evolving concepts was Project Based Learning (PBL) which was popular across many education fields: the main essence of it is involving the students in an authentic and practical translation project. This article investigates the experiences of Saudi under-preparation-translators in a Computer Aided Translation (CAT) course that was introduced using the PBL method. Using qualitative methods (mainly interviews and observations), students' receptions were collected and analyzed and themes were elicited to report the students' attitude to PBL method. Although many positive experiences such as autonomy and team work skills were reported, some indicated the concerns of the practicality of the procedure as well as time issues.

Keywords: Computer Aided Translation, method, perceptions, Project-Based-Learning, Saudi translators, Translation

Cite as: Alkhatnai, M. (2017). Teaching Translation Using Project-Based-Learning: Saudi Translation Students Perspectives. Arab World English Journal for Translation \& Literary Studies, 1(4).

DOI: http://dx.doi.org/10.24093/awejtls/vol1no4.6
\end{abstract}

